\title{
JÓZEF BANIAK \\ Kierunki zmian w postawach i zachowaniach rytualnych katolików miejskich. Analiza socjologiczna
}

Rytualistyka katolicka jest bogata w swej formie i ma własna specyfikę. W jej skład wchodzi wiele różnych rytuałów, które ludzie wierzący i religijni moga lub powinni spełniać we własnym życiu religijnym. Jednostka ludzka w toku całego roku uczestniczy w dużej liczbie rytuałów - świeckich i religijnych. Z socjologii religii wiadomo, iż istnieją rytuały laickie i religijne, rytuały cyklów i kryzysów egzystencjalnych, rytualy rodzinne i doroczne, rytuały lokalne i regionalne oraz narodowe, rytualy estetyczne, obyczajowe i moralne itp ${ }^{1}$. Wspomniana wielość i różnorodność rytualów znacznie utrudnia ich analizę w rozprawach naukowych wąsko zakresowych. Nie sposób bowiem nawet pokrótce ukazać istotę tak licznych zdarzeń rytualnych w takiej rozprawie, jeśli weźmiemy pod uwagę postawy i zachowania ludzi związane z każdym rytualem. Możliwe więc jest dokładne ukazanie wybranych rytualów, jeśli ulokujemy je w konkretnej perspektywie humanistycznej. Z tego powodu w artykule tym uwagę skoncentruję jedynie na niektórych rytuałach religijnych, które znajdują się w zakresie obowiązków podstawowych katolika, a ściślej na stopniu ich przestrzegania przez katolików według norm ustalonych przez dyscyplinę kościelna.

Warto zatem przypomnieć, czym są w swej istocie rytuały religijne? Wiedza ta ułatwi zrozumienie postrzegania rytuałów przez katolików, jak i stosowanie ich w praktyce religijnej. Idac za Władysławem Piwowarskim, można powiedzieć, że rytuałami religijnymi sa tylko takie zdarzenia rytualne, w których ujawnia się odniesienie jednostki do rzeczywistości pozaempirycznej. Inne zda-

${ }^{1}$ Zob. R. Boock: Ritual in Industrial Society, A sociological analysis of ritualism in modern England. London 1974 s. 35; J. Baniak: Istota, funkcje i ewolucja rytuału religtjnego. „Studia Socjologiczne". R. 1992 nr 1-2 s. 91-111. 
rzenia rytualne, choćby spełniały pewne funkcje religijne, nie sa rytuałami religijnymi $^{2}$. A zatem rytual religijny jest zorientowany na „,sacrum", co jest widoczne $w$ jego symbolach, treści i wartościach. W rytuale religijnym ludzie wierzący sami przeżywają sacrum, pogłębiają osobistą więź z Bogiem i tworzą wspólnotę religijna. W rytuale tym jednostki religijne przede wszystkim nawiązują lączność z Bogiem, jako z ostateczną rzeczywistością i z transcendentnym autorytetem ${ }^{3}$.

Rytuały religijne, analogicznie jak rytuały świeckie, pozostają w relacji do symboli, co często powoduje zle ich zrozumienie w codziennym życiu religijnym katolików. Badacze tego problemu mówią wówczas o dwóch rodzajach niebezpieczeństwa $w$ interpretacji zdarzeń rytualno-religijnych. Pierwsze niebezpieczeństwo sygnalizuje Th. O Dea, mówiąc, iż symbole są przedmiotem napięcia w rytuale religijnym. Napięcie to wynika z ich subiektywnego charakteru (uzewnętrzniają religijne postawy i ,materializują" religijne znaczenia) oraz z ich obiektywizacji i rutynizacji (stają się w ramach czasu utrwalonym i ciagle powtarzanym schematem). Napięcie to powoduje, iż symbole religijne tracą związek z emocjami i postawami, a więc tracą subiektywne znaczenie, alienując się, stając się niezrozumiałymi lub zaczynają służyć wartościom innym niż religijne, np. wzmocnieniu więzi rodzinnej ${ }^{4}$. O drugim niebezpieczeństwie mówi Mircea Eliade, wskazując na proces infantylizacji symboli religijnych ${ }^{5}$. Zjawisko to jest widoczne wtedy, kiedy w świadomości ludzi symbol jest traktowany in extenso, w sposób ukonkretniony i niedojrzały. Wtedy na przykład ,,gorliwy” katolik w obrazie Madonny Częstochowskiej ,,widzi” naprawdę obecną Matkę Boską, obraz ten faktycznie utożsamia z obecnością w nim osoby Matki Boskiej. O tym zjawisku warto pamiętać wtedy, kiedy analizujemy udział katolików w różnych rytuałach religijnych, jak i ich moralność rytualna, deklaracje ich przekonań i zachowań rytualnych, jakie składają podczas badań socjologicznych.

Rytuały religijne spełniaja wiele funkcji w życiu ludzi wierzacych - są to albo funkcje religijne, albo funkcje pozareligijne ${ }^{6}$. W zakresie funkcji religijnych rytuał religijny pogłębia więź jednostki z sacrum, ułatwia jednoczenie się ludzi w plaszczyźnie religijnej i umożliwia odnowę moralną w wymiarze indywidual-

\footnotetext{
${ }^{2}$ W. Piwowarski: Socjologia rytualu religijnego. Zarys problematyki. „Roczniki Nauk Społecznych". T. 11: 1983 s. 8.

${ }^{3}$ Por. B.S. Turner: Belief and Experience. The Case of Methodism. „Social Compass”. R. $1971 \mathrm{nr} 18$ s. 190.

${ }^{4}$ Th. O. Dea: The Sociology of Religion. Englewood Cliffs 1966 s. 92-95.

${ }^{5}$ M. Eliade: Patterns in Comparative Religion. New York 1958 s. $444-456$.

${ }^{6}$ Por. K. Żygulski: Święto i kultura, święta dawne i nowe. Rozważania socjologa. Warszawa 1981 s. 136; B. Wilson: Religion in sociological Perspective. Oxford-New York 1982 s. $45-48$.
} 
nym i społecznym. W zakresie funkcji pozareligijnych rytuał religijny umożliwia lub pogłębia procesy integracyjne $w$ grupie religijnej, mając zarazem drugorzędne znaczenie $\mathrm{w}$ religijności jednostek i grup ludzkich ${ }^{7}$. Władysław Piwowarski, idąc za innymi socjologami religii, wskazuje na trzy najważniejsze funkcje religijne rytuału religijnego: a) funkcja nawiązania, podtrzymania i pogłębienia więzi z sacrum; b) funkcja pogłębienia więzi między ludźmi w sferze religijnej; c) funkcja przemiany moralnej jednostek i zbiorowości ludzkich ${ }^{8}$. Ponadto, rytuał religijny przyczynia się do integracji ludzi wierzących z sobą w płaszczyźnie życia religijnego.

W przekonaniu socjologów religii i kultury, uczestnictwo w rytuale religijnym sprowadza na ludzi następujące skutki społeczne: a) stwarza możliwość pocieszenia i pojednania, minimalizując rozczarowanie, rozładowując konflikty i wzmacniając morale; b) ułatwia bezpieczeństwo i identyczność w sytuacji przemian, zdarzeń losowych i ingerencji czynników zewnętrznych, przyczyniając się do stabilności, porządku i trwałości; c) wspiera wartości społeczeństwa stabilnie egzystującego, eksponując cele wspólne ponad cele indywidualne, legitymizuje normy i wzory zachowań, sakralizuje wartości, a osobom nie przestrzegającym tych norm zapewnia rekoncyliację i bezpieczny powrót do grupy społecznej; d) integruje ludzką osobowość, ukazując jednostce perspektywę ostateczności, przypomina jednostkom ,kim one są i czym one są"; e) wspomaga jednostkę w procesie rozwoju osobniczego i adaptacji egzystencjalnej na poszczególnych etapach jej biografii, ułatwiając jej pokonanie wszelkich trudności i przeszkód, na które napotka ona na własnej drodze życia ${ }^{9}$. W świetle tego można więc powiedzieć, że jeśli rytual religijny jest poprawnie interpretowany przez jednostki, to spełniając te liczne funkcje w ich życiu religijnym, staje się wyrazem ich doświadczenia religijnego, utrwalonym w formie instytucji funkcjonującej w konkretnych warunkach miejsca i czasu.

Udział katolików w rytuałach religijnych reguluje zespól norm etycznych i moralnych, które stanowią elementy składowe dyscypliny kościelnej. Tak, jak liczne są rytualy, podobnie wiele jest norm etyczno-moralnych stojących na stra-

${ }^{7}$ Zob. F. Houtart, J. Remy: Eglise et societe on mutation. Paris 1959 s. 173; R.K. Merton: Teoria socjologiczna i struktura społeczna. Warszawa 1982 s. 92-152 (131-134).

${ }^{8}$ W. Piwowarski: Funkcje rytualu religijnego. W: Rytuat religijny w rodzinie. WarszawaPoznań 1988 s. 79-84; zob. O. Bischofberge r: Wesen und Sinn des Ritus. W: J. Baumgartner (Hrsg.): Wieder-Endeckung der Volksreligiositat. Regensburg 1979 s. 154; S. Mowincke1: Religion und Kultus. Gottingen 1953 s. 53-54; J. Casenevue: Sociologie du rite. Paris 1971 s. 15; M. Mead: Ritual and Social Crisis. W: J.D. Shaughnessy: Ritual in Industrial Society. London 1974 s. 39-42; R. Boo ck: The Roots of Ritual. Grand Rapids 1973 s. 54-59.

${ }^{9}$ Zob. R. Nisbet: The Sociological Tradition. London 1967 s. 80; K. Davis: Human Society. New York 1948 s. 24; W. Piwowarski: Funkcje rytuatu religijnego, art. cyt., s. 85-86. 
ży przestrzegania lub spełniania poszczególnych rytuałów, przyczyniając się w efekcie do moralnej przemiany ludzi wierzących. Warto tu dodać, iż w chrześcijaństwie przemiana moralna wykracza poza wszelkie kodeksy moralne. Przemiana ta uwzględnia bowiem internalizację ideałów ewangelicznych, przezwyciężanie zla istniejącego w czlowieku i ,narodzenie się” nowego czlowieka, milość wszystkich ludzi, lącznie z nieprzyjaciółmi, budowanie wspólnoty ludzkiej, eliminując przy tym egoizm a eksponując wiarę, nadzieję i miłość. Fakt ten oznacza więc, iż moralność rytualna katolików jest zagadnieniem złożonym, co z kolei utrudnia dokładną jego analizę w przyjętych rygorach metodologicznych, nakładając jednocześnie konieczność eksponowania wybranych skladników.

Mając na uwadze powyższe trudności, w tym artykule uwage skupię jedynie na niektórych elementach moralności rytualnej katolików, próbując zarazem odpowiedzieć na następujące pytania: Czy katolicy miejscy znają normy rytualne, które obowiązują ich jako czlonków Kościoła? Jaki jest stosunek katolików miejskich do norm rytualnych i do dyscypliny kościelnej z zakresu tej sfery życia religijnego i moralności? Jakie zmiany nastapiły w przyjętym okresie w nastawieniu i w realizacji rytualów religijnych w badanym środowisku katolików miejskich w Kaliszu? Czy ewentualne zmiany mają tendencję negatywną, czy też tendencje pozytywną?

Problem ten wyjaśnię w zakresie dwóch płaszczyzn - postaw i zachowań rytualnych katolików miejskich. Praktycznie więc uwzględnię tu jedynie następujące normy obowiązujące katolików: normę nakazujacca im zachowywanie postów, normę nakazującą szacunek autorytetom religijnym oraz normę nakazująca im udział w mszy niedzielnej. Analizą obejmę zarówno stosunek katolików miejskich do tych norm, jak i zakres przestrzegania ich według rygorów ustalonych przez Kościół katolicki. Podstawę tej analizy stanowią wyniki moich dwukrotnych badań socjologicznych, jakie zrealizowałem w Kaliszu w roku 1987 i 1997 wśród dwóch statystycznie reprezentatywnych grup respondentów, mieszkańców tego miasta, liczących po 1200 osób. Artykuł ten stanowi zaledwie fragment szerszej monografii dotyczącej zmian w religijności i moralności katolików miejskich, jakie nastapily na kanwie transformacji systemowych w kraju i na świecie.

\section{Stosunek katolików miejskich do norm rytualnych dotyczących postu}

Na stosunek katolików do norm nakazujących posty okresowe istotnie oddziałuje środowisko stałego ich zamieszkania - miasto i wieś. Na wsi posty respektowane są liczniej i częściej niż w mieście, o czym informują badacze reli- 
gijności. Kościół zmienił kalendarz postów, liberalizując przepisy ich dotyczące. Zmianie uległy wymogi Kościoła wobec katolików, jak również wzory postów ugruntowane w kulturze spoleczności lokalnej, a znane i kultywowane także w kulturze miejskiej ${ }^{10}$. Nowe przepisy rytualne Kościoła także są różnorodnie rozumiane i interpretowane przez wiernych świeckich. Pewna ich część uważa, że posty zostały zniesione całkowicie przez Kościól, z kolei inni twierdza, że posty nie obowiązuja, choć jeszcze formalnie istnieją ${ }^{11}$.

W związku z tymi poglądami i opiniami ważne okazało się zbadanie postaw katolików miejskich w Kaliszu wobec norm nakazujących zachowywanie postów w dni roku ustalone przepisami kościelnymi, w obu terminach badań; ważne jest także dostrzeżenie zmian $\mathrm{w}$ ich nastawieniu do tych norm rytualnych $\mathrm{w}$ przyjętym okresie. Dokonałem tego, pytając respondentów w obu terminach, czy katolicy powinni zachowywać posty zgodnie z postulatami rytualnymi Kościoła? Wypowiedzi ich na to pytanie ukaże tabela 1 , uwzględniając oba terminy badań

Tabela 1. Akceptacja normy nakazującej zachowywanie postów okresowych

\begin{tabular}{|l|r|r|r|r|}
\hline \multirow{2}{*}{$\begin{array}{c}\text { Akceptacja normy } \\
\text { rytualnej }\end{array}$} & \multicolumn{2}{|c|}{ Badania I. } & \multicolumn{2}{c|}{ Badania II. } \\
\cline { 2 - 5 } Całkowicie & \multicolumn{1}{c|}{ Liczba } & \multicolumn{1}{c|}{ Procenty } & \multicolumn{1}{c|}{ Liczba } & \multicolumn{1}{c|}{ Procenty } \\
\hline Częściowo & 175 & 14,3 & 117 & 9,8 \\
\hline Nie akceptuje & 629 & 51,4 & 466 & 38,8 \\
\hline Nie wiem & 313 & 25,6 & 478 & 39,8 \\
\hline Brak danych & 79 & 6,6 & 91 & 7,6 \\
\hline Ogółem & 26 & 2,1 & 48 & 4 \\
\hline
\end{tabular}

O ile w badaniach pierwszych większość respondentów (65,7\%) akceptowała w różnym stopniu normę rytualną nakazującą przestrzeganie postów okresowych, to w drugich odsetek akceptujących jest już znacznie mniejszy $(48,6 \%)$. Różnica $(17,1 \%)$ między obu tymi wskaźnikami akceptacji normy jest znaczna i

${ }^{10}$ Zob. W. Piwowarski: Religijność wiejska w warunkach urbanizacji. Studium socjologiczne. Warszawa 1971 s. 247; J. Baniak: Religijność miejska w warunkach ruralizacji i uprzemystowienia na przykładzie Kalisza. Studium socjologiczne. UJ, Kraków 1990 s. 46—56.

${ }^{11}$ Zob. J. Mariański: Dynamika przemian religijności wiejskiej w warunkach industrializacji w rejonie plockim. Studium socjologiczne. Warszawa-Poznań 1984 s. 256. 
oznacza zarazem ujemną tendencję w postawach katolików kaliskich do postów, jak i do normy go nakazującej. Tendencję tę potwierdza także wzrost w drugim terminie badań odsetka respondentów odrzucających tę normę rytualną o 14,2\%. Zatem w badanym dziesięcioleciu zmieniło się nastawienie katolików miejskich do tej normy rytualnej z pozytywnego na negatywne, dając tego wyraz w postawach wielu respondentów.

Respondenci, akceptujący normę rytualną nakazująca posty katolikom, własną postawę uzasadniali różnymi motywami, a sytuacja ta wystapiła w obu terminach badań, choć z pewnymi odmiennościami. Motywy wskazane przez nich można zgrupować w trzech kategoriach ogólnych: 1) religijne - ekspiacja za grzechy, chęć naśladowania Jezusa, miłość do Boga, lepsze przeżycie świąt religijnych, umocnienie własnej wiary, wyproszenie lask u Boga potrzebnych w życiu, pokuta za grzechy ludzi i własne; 2) kościelne - Kościół nakazuje pościć, nie zachowywanie postu oznacza grzech ciężki, księża zalecaja post a ludzie powinni uszanować ich wolę i polecenie, przez post czuję się ściślej złączony(a) z Kościolem, Kościól jest instytucją Jezusa a Jego wolę i wolę Kościoła trzeba szanować i spełniać; 3) wynikające $z$ tradycji i obyczajów - post to już stara tradycja w narodzie polskim, obyczaje przodków należy respektować i szanować, w mojej rodzinie zawsze się pości dla dobra duszy, zwyczaj ten zachowuja rodziny katolickie z pokolenia na pokolenie itp. Wskaźniki akceptacji (wysunięcia) tych motywów są w obu terminach następujące: religijne - 52,4\% i 43,7\%; kościelne - 16,3\% i 12,2\%; wynikające z tradycji i obyczaju - $24,7 \%$ i $36,7 \%$; brak motywów - 4,6\% i 7,4\%. A zatem zdecydowanie dominuja motywy religijno-kościelne, uzasadniające akceptację moralnej normy kościelnej, nakazującej katolikom zachowywanie postów w ustalonych terminach kalendarza. Wydaje się, iż w dużym stopniu z motywami religijnymi łączą się motywy związane $\mathrm{z}$ tradycją rodzinną i ogólnokościelna. Natomiast dla 1/4 i $1 / 3$ badanych katolików post nie ma uzasadnienia i znaczenia religijnego. Stąd kwestionują i odrzucaja oni normę nakazująca katolikom post w stosownych terminach kalendarza kościelnego. W przekonaniu niektórych obecnie ,,posty są już zbyteczne”, ,wyszły już mody”, ,w życiu i tak jest ciężko, więc po co utrudniać je postami”, ,,posty nie dają nic dobrego, a więc i religijności nie ulepsza”, ,nie widzą potrzeby poszczenia dzisiaj, kiedy i tak dieta jest słabo kaloryczna przez kryzys gospodarczy" itp. Te laickie powody zyskały uznanie u większego odsetka respondentów w drugim okresie, a jednocześnie zmniejszył się odsetek osób uzasadniających akceptację postów względami religijnymi i kościelnymi. W ten sposób zyskujemy kolejny czynnik wskazujący na wzrost negatywnego nastawienia katolików w badanym okresie do norm moralności rytualnej.

Do normy nakazującej posty inaczej ustosunkowali się respondenci deklarujący pozytywny stosunek do wiary i religii, a inaczej deklarujący stosunek nega- 
tywny lub obojętny. Znaczenie postów w życiu religijnym katolików, jak i normy je nakazującej, docenili $\mathrm{w}$ obu terminach w szczególności respondenci głęboko wierzący $(88,6 \%$ i $71,3 \%)$ i wierzący $(71,4 \%$ i $65,4 \%)$. Natomiast wskaźniki tej akceptacji są już znacznie niższe w zbiorze wątpiących religijnie $(31,7 \%$ i $23,5 \%)$ i obojętnych religijnie (16,8\% i 13,3\%), zaś najmniej akceptujących posty jest wśród niewierzących, choć powiązanych w pewnym stopniu z tradycjami religijnymi $(4,0 \%$ i $5,3 \%)$. Normę tę odrzucili w obu terminach w stu procentach respondenci niewierzący i jednocześnie nie spełniający praktyk. W badanym środowisku miejskim dostrzegłem wyraźną radykalizację postaw katolików wobec tej normy rytualnej, która wskazuje zarazem, iż dla nich post nie ma znaczenia $\mathrm{w}$ życiu, a nadto rzadziej uzasadniają go motywami religijnym ci, którzy normę tę akceptują ${ }^{12}$.

\section{Postawy katolików wobec normy nakazują̧cej udział w mszy niedzielnej i świątecznej}

Uczestnictwo w mszy niedzielnej i świątecznej jest dla katolików podstawowym obowiązkiem, ujętym w sankcję grzechu ciężkiego. Jedynie z ważnych i uzasadnionych powodów niektórzy katolicy mogą opuścić mszę niedzielną lub świąteczną, na co Kościół im zezwala na mocy specjalnej dyspensy. Surowość normy nakazującej udział w mszy tej znają wszyscy katolicy, nawet nie spełniający praktyk, choć różny jest ich stosunek do jej obowiązywalności. Na występowanie takiego zróżnicowania wskazują liczne badania socjologiczne. Ten stan rzeczy pozwalał $w$ obu terminach na zbadanie postaw katolików wobec normy nakazującej uczestnictwo w mszy niedzielnej i świątecznej w środowisku miejskim Kalisza. Zapytalem więc wtedy moich respondentów, czy udział w tym obowiazku religijnym jest w ich odczuciu (ocenie) obligatoryjny dla wszystkich katolików pod sankcją grzechu ciężkiego? Własne stanowisko badani katolicy mieli także uzasadnić, niezależnie od jego charakteru. Wypowiedzi ich ilustruje tabela 2, uwzględniająca oba terminy badań.

\footnotetext{
${ }^{12}$ Por. W. Piwowarski: Religıjność miejska w rejonie uprzemyslowionym. Studium socjologiczne. Warszawa 1977 s. 227, tabl. 48 (Autor ten informuje, że jego respondenci akceptowali posty w następujących odsetkach: w Puławach - 67,3\%, w Kazimierzu - 79,3\%, w Płocku $63,0 \%)$.
} 
Tabela 2. Akceptacja normy nakazıjącej udzial w mszy niedzielnej i świątecznej

\begin{tabular}{|l|r|r|r|r|}
\hline \multirow{2}{*}{$\begin{array}{c}\text { Akceptacja } \\
\text { normy }\end{array}$} & \multicolumn{2}{|c|}{ Badania I } & \multicolumn{2}{c|}{ Badania II } \\
\cline { 2 - 5 } Akceptuje & \multicolumn{1}{|c|}{ Liczba } & \multicolumn{1}{c|}{ Procenty } & \multicolumn{1}{c|}{ Liczba } & \multicolumn{1}{c|}{ Procenty } \\
\hline Nie akceptuje & 549 & 44,9 & 393 & 32,7 \\
\hline Bez stanowiska & 482 & 39,4 & 577 & 48,1 \\
\hline Brak danych & 158 & 13,1 & 187 & 15,6 \\
\hline Ogółem & 33 & 2,6 & 43 & 3,6 \\
\hline
\end{tabular}

W obu terminach badań dostrzeglem brak jednomyślności wśród respondentów wobec tej ważnej dla życia religijnego normy rytualnej. Nie wszyscy badani byli przekonani co do jej zasadności i konieczności w życiu religijnym katolików. Z danych wynika, że jedynie pewne ich odsetki akceptowały tę normę bez zastrzeżen. Ponadto, w drugim terminie badań dał się zauważyć regres odsetka akceptujących tę normę rytualną o $7,2 \%$. Wskaźnik ten oznacza, iż w badanym okresie 10 lat nastapił wzrost liczby katolików, którzy nie akceptowali jej z różnych powodów i motywów. Wzrost ten wynosi $8,7 \%$ w stosunku do wskaźnika z pierwszego terminu badań w 1987 r. W tym okresie wzrósł też odsetek katolików, którzy nie potrafili zająć stanowiska w tej kwestii, więc nie udzielili odpowiedzi na postawione pytanie podczas badań. Zatem i w tej kwestii dostrzegamy w świetle wyników badań ujemną tendencję w nastawieniu katolików kaliskich do normy rytualnej nakazującej im (i innym katolikom) udział w mszy niedzielnej i świątecznej, jaka wystapiła w tym właśnie okresie. Wielu z nich, zwłaszcza ci, którzy odrzucali tę normę zdecydowanie, stwierdzało otwarcie, iż ,,jest ona zbyt rygorystyczna”, ,,jest przesadnie ostra i nakazowa”, ,za bardzo niepraktyczna i nieludzka”, „,bardziej troszczy się o dobro Kościoła instytucjonalnego, aniżeli jednostki religijnej" itp ${ }^{13}$.

Obowiązek udziału w mszy niedzielnej i świątecznej, jak i absencję w niej, inaczej postrzegają i oceniaja respondenci wierzacy, a inaczej respondenci niewierzący badani w obu terminach. Normę nakazującą ten udział akceptują bez zastrzeżeń przede wszystkim osoby głęboko wierzące $(74,6 \%$ i $68,2 \%)$, lecz już

${ }^{13}$ Por. Tamże, s. 228 (Autor informuje, że w Płocku opuszczenie celowe mszy niedzielnej uznało za grzech ciężki 39,9\% respondentów, a 34,4\% było przeciwnych tej ocenie, zaś 23,9\% nie potrafiło zająć stanowiska jednoznacznego w tej kwestii). 
w mniejszych odsetkach wierzący $(53,8 \%$ i $44,2 \%)$. Odsetki respondentów akceptujących ją maleją radykalnie $w$ pozostalych trzech kategoriach poziomu wiary, osiaggając w grupie wątpiacych zaledwie $18,6 \%$ i $12,5 \%$, w grupie obojętnych religijnie $9,7 \%$ i $6,6 \%$ oraz w grupie niewierzacych $6,9 \%$ i $3,5 \%$. Z kolei w grupie zdeklarowanych ateistów w obu terminach badań wszyscy byli przeciwni tak surowej ocenie absencji katolików w niedzielnej i świątecznej mszy.

Ogólnie można więc powiedzieć, iż stopień akceptacji normy rytualnej wskazującej na obowiązek udziału katolików w mszy niedzielnej i świątecznej jest stosunkowo niski w środowisku katolików miejskich w Kaliszu. Co więcej, w uwzględnionym przedziale czasu nastapił wyraźny regres odsetka osób akceptujących tę normę rytualną, a jednocześnie wzrósł odsetek osób ją wyraźnie kwestionujących i odrzucających. Akceptację i negację tej normy warunkuja dość istotnie takie czynniki, jak np. Pochodzenie środowiskowe badanych, okres pobytu w Kaliszu, poziom ich wiary i religijności, pleć i wykształcenie.

\section{Postawy katolików wobec autorytetów moralnych i kościelnych}

Sfera życia moralnego katolików jest szeroka i obejmuje swoim zasięgiem wiele różnych kwestii i problemów o charakterze jednostkowym i społecznym. Sfera ta wymaga od jednostek ludzkich podejmowania decyzji, dokonywania wyborów moralnych, umiejętności rozstrzygania różnych konfliktów moralnych, oceny własnego i innych ludzi postępowania. W związku z tym, ważne wydaje się pytanie, czym najbardziej kierują się ludzie wierzacy w wyborach i preferencjach moralnych i etycznych? Jakie autorytety wpływają na ich decyzje dotyczace ważnych spraw i problemów moralnych? Czyim sugestiom są oni ,ulegli” najbardziej w tym zakresie? Czy na moralność katolików mają wpływ autorytety religijne i kościelne? Czy autorytety te oddziałują także na sumienia katolików? Niektóre problemy podniesione $w$ tych pytaniach wyjaśnię $w$ dalszej analizie, wykorzystując w tym celu wypowiedzi moich respondentów z obu badań w Kaliszu.

W założeniach metodologicznych badań przyjąłem hipotezę, iż wśród licznych czynników pomagającym ludziom w rozstrzyganiu konfliktów moralnych i w podejmowaniu ważnych decyzji życiowych, podstawową rolę odgrywają religia i Kościól katolicki, a wplyw tych czynników na moralność jednostkową i zbiorowa jest najsilniejszy w sytuacji osób wierzących. Chcąc zweryfikować zasadność tej hipotezy, a tym samym zbadać poglądy ludności miejskiej na ten temat, postawilem własnym respondentom podczas obu badań następujące pytanie: Jakimi autorytetami kierują się w rozwiązywaniu konfliktów moralnych oraz w podejmowaniu ważnych decyzji egzystencjalnych? Do tego pytania dołączyłem siedem czynników (autorytetów), prosząc o wskazanie tych, które faktycznie 
oddziałują na moralność każdego z badanych katolików. Preferencje dokonane tu przez respondentów ilustruje tabela 3 , biorąc pod uwagę oba badania.

Tabela 3. Akceptaça autorytetów wpływających na moralność katolików

\begin{tabular}{|l|r|r|r|r|}
\hline \multirow{2}{*}{ Rodzaj autorytetu } & \multicolumn{2}{|c|}{ Badania I } & \multicolumn{2}{c|}{ Badania II } \\
\cline { 2 - 5 } & \multicolumn{1}{|c|}{ Liczba } & \multicolumn{1}{c|}{ Procenty } & \multicolumn{1}{c|}{ Liczba } & \multicolumn{1}{c|}{ Procenty } \\
\hline Sumienie własne & 1062 & 86,9 & 957 & 79,7 \\
\hline Normy religijne & 414 & 33,8 & 336 & 28,1 \\
\hline Rodzina & 330 & 27,1 & 462 & 38,4 \\
\hline Księża & 151 & 12,3 & 97 & 8,1 \\
\hline Normy świeckie & 185 & 15,1 & 283 & 23,6 \\
\hline Przyjaciele & 139 & 11,3 & 154 & 12,8 \\
\hline Interes własny & 319 & 26,1 & 380 & 31,7 \\
\hline Nie wiem & 92 & 7,5 & 114 & 9,5 \\
\hline Brak danych & 59 & 4,8 & 62 & 5,2 \\
\hline Ogółem badani & 1222 & - & 1200 & - \\
\hline
\end{tabular}

Wyniki badań nie potwierdzily pełnej zasadności i trafności przyjętej hipotezy empirycznej, ponieważ autorytety religijne (normy, księża, instytucje kościelne) nie odgrywają głównej roli i nie mają dominującego wplywu na życie wszystkich respondentów, a takie było jej założenie. Sytuacja ta ma miejsce w obu terminach badań środowiskowych. W pierwszych badaniach jedynie niespełna $1 / 3$, a w drugich badaniach ponad $1 / 4$ respondentów uznała autorytety religijne jako podstawowe czynniki pomagające ludziom w rozwiązywaniu problemów moralnych i w podejmowaniu ważnych decyzji życiowych. Co więcej, po uplywie 10 lat zmalal o niespełna $10 \%$ odsetek katolików preferujących znaczenie roli tych autorytetów w życiu ludzi, a jednocześnie wzrósł odsetek o 35,6\% osób powątpiewających $w$ ich znaczenie, jak i wyraźnie je odrzucających jako znaczące egzystencjalnie. Także księża katoliccy nie są dla większości respondentów autorytetami moralnymi, jeśli $z$ ich rad i wskazań czy opinii etycznych skorzystałoby lub korzystało w pierwszym terminie niespełna 13\%, a w drugim terminie jedynie co 12 spośród badanych. Na pytanie kontrolne w tej kwestii, aż $53,7 \%$ i $67,2 \%$ badanych katolików miałoby wyraźne wątpliwości co do tego, 
czy poprosiloby księdza o radę lub opinię w ważnej sprawie życiowej i trudnym problemie moralnym. Najbardziej i największy odsetek badanych osób nie ufa księżom w sprawach związanych z życiem seksualnym, z erotyka, małżeństwem i rodzina, jak i ostro krytykują wlączanie się kleru i instytucji Kościola w wychowanie seksualne młodzieży szkolnej. Krytycyzm ten nasilił się wyraźnie w drugim terminie badań, a widoczny jest on już niemal w całym dziesięcioleciu. Respondenci, zwlaszcza rodzice, są bardzo wrażliwi na informacje o patologicznych zachowaniach seksualnych księży i zakonników, często wskazywali na podobne inklinacje i zachowania duchownych we własnych lub znanych sobie środowiskach parafialnych. Warto dodać, iż aż 57,3\% i 66,8\% respondentów ocenilo bardzo krytycznie metodykę nauczania religii stosowaną przez księży i zakonnice (,oni nie mają pojęcia, jak porządnie uczyć i wychowywać nasze dzieci, bo nie mają swoich dzieci”, ,to czysta teoria, polegająca na szerzeniu ideologii katolickiej, a nie żadne wychowanie człowieka”, „naszego księdza interesują tylko spokojne dziewczynki, a nie nauka o Bogu, bo nie umie uczyć i wychowywać" - to często pojawiające się wypowiedzi respondentów na ten temat, jak i sondujące ich opinie o moralności tych autorytetów). W konsekwencji więc dominujące odsetki badanych osób w obu terminach uznały własne sumienie za główny czynnik biorący udział w rozstrzyganiu istotnych problemów moralnych i życiowych. Bazując na własnej wiedzy i na doświadczeniu życiowym, często wspartym rada rodziców, rodziny czy zaufanych przyjaciół lub kompetentnych autorytetów świeckich, najczęściej sami próbują rozwiązywać osobiste problemy czy podejmować wiążące decyzje egzystencjalne. W związku z tym warto przypomnieć, iż w ocenie wielu współczesnych moralistów, sumienie jest w szczególności ,zjawiskiem moralnym" i jako takie najczęściej występuje jako kryterium rozstrzygnięć moralnych u tych osób, które nie stosują się do norm religijnych we własnym postępowaniu moralnym, a religia nie jest wskaźnikiem ich zachowań moralnych ${ }^{14}$. W ocenie B. Haeringa, sumienie jest dla każdego człowieka ostateczna, subiektywną normą zachowań moralnych. Jednakże, jeśli człowiek chce postępować prawidłowo, musi - jego zdaniem - zawsze poszukiwać własnej normy obiektywnej w postaci autorytetu zewnętrznego. Dla osoby religijnej, wierzacej w Boga osobowego, taką normą ,odniesienia etycznego" (autorytetem) jest religia i Kościól, do którego czlowiek ów należy i korzysta $\mathrm{z}$ nauki Kościola ${ }^{15}$. Prezentowane tu, jak i inne badania naukowe, wskazują wyraźnie, iż liczni katolicy postępują wbrew intencjom i założeniom doktry-

${ }^{14}$ Zob. A. Just: Formowanie sie sumienia. W: W kierunku czlowieka. Warszawa $1971 \mathrm{s.}$ 276-278; W. Szewczuk: Sumienie. Studium psychologiczne. Warszawa 1988 s. 117-204; T. Kotarbiński: Sprawy sumienia. Warszawa 1956 s. 23-34; R. Dyoniziak: Mlodzieżowa podkultura. Warszawa 1965 s. 110-112.

${ }^{15}$ B. Haering: Nauka Chrystusa. T. 1. Zasadnicza postać chrześcijańskiego życia. Poznań 1962 s. $164-165$. 
nalnym Kościoła wskazywanym przez tego teologa. Stąd ani normy religijne, ani tym bardziej opinie osób związanych ,,zawodowo" z religią (księży), nie zajęly znaczacej pozycji w preferencjach aksjologicznych i moralnych bardzo licznych katolików polskich, w tym w Kaliszu. Tu w badanym okresie wzrósł odsetek tych respondentów, którzy nie kierowali się normami religijnymi w rozwiązywaniu własnych problemów moralnych, zarówno w sferze życia osobistego, jak i w sferze życia publicznego.

Należy zaznaczyć, iż sumienie miało największe znaczenie w życiu moralnym tak dla rdzennych kaliszan, jak i dla imigrantów wiejskich, którzy w tym mieście zamieszkali na stałe, choć ich wskaźniki nie są bynajmniej identyczne. Normy religijne eksponowali liczniej autochtoni, niż imigranci wiejscy (o 17,2\% i $13,5 \%$ ), a także oni częściej liczyli się z ocenami moralnymi księży (o $0,5 \%$ i $1,6 \%)$. Wychodźcy wiejscy rzadziej niż autochtoni miejscy kontaktują się $\mathrm{z}$ księżmi parafialnymi, są bardziej krytyczni wobec duchownych i wobec ich zachowań moralnych. Postawy te nie są obojętne dla preferencji autorytetów, jakich dokonywali w obu terminach badani katolicy. Autorytety religijne zajęy w ich wskazaniach drugoplanowe miejsce, a księża pozycje jeszcze odleglejsze w tej hierarchii znaczeń moralnych.

Preferencje autorytetów moralnych dokonywane przez respondentów różnicuje istotnie ich osobisty stosunek do wiary i religii. Jednakże i w tym przypadku sumienie jest normą najważniejszą dla osób wierzących i niewierzących, a nawet bardziej docenianą w ich środowisku, niż w środowisku osób watpiących i niezdecydowanych w sprawach religijnych. Warto więc zaznaczyć, iż sumienie było akcentowane przez $63,7 \%$ i $78,9 \%$ glęboko wierzących i przez $48,2 \%$ i $60,3 \%$ wierzących. Z kolei normy religijne miały pierwszorzędne znaczenie w moralności dla $41,9 \%$ i $38,8 \%$ glęboko wierzacych oraz dla $37,1 \%$ i $40,4 \%$ wierzących, a wskazania księży dla 35,5\% i 25,9\% respondentów z obu tych grup. Natomiast osoby niewierzace wskazywały przede wszystkim na rolę sumienia $(71,4 \%$ i $84,7 \%)$, rolę rodziny $(63,3 \%$ i $72,5 \%)$ i na własne korzyści życiowe $(43,5 \%$ i $49,8 \%$ ), lecz zarazem jedynie sporadycznie mówily o roli norm religijnych ( $3,6 \%$ i $2,8 \%)$ oraz o roli ocen duchowieństwa $(0,8 \%$ i $1,3 \%)$. W grupie respondentów wątpiących aż $57,4 \%$ i $585 \%$ oraz wśród obojętnych religijnie aż $60,6 \%$ i $65,7 \%$ nie zajęlo własnego stanowiska w tej kwestii, a zarazem najliczniejsze ich odsetki wyraźnie akcentowaly rolę sumienia $(36,3 \%$ i $42,6 \%$ oraz $32,1 \%$ i $40,7 \%)$ w rozwiązywaniu spraw i problemów moralnych. Dla nich też sumienie jest tu największym autorytetem, dlatego jemu ufają całkowicie i nim się kieruja w podejmowaniu trudnych decyzji życiowych.

W świetle tych wskaźników empirycznych można stwierdzić ogólnie, iż szczególne preferowanie roli sumienia i norm świeckiej moralności jako osta- 
tecznej i powszechnej niemal normy etycznej, a zarazem wyraźne niedocenianie roli autorytetów religijnych, nasuwa konkluzję o niewielkim jedynie wplywie religii i instytucji Kościoła na wybory moralne i egzystencjalne katolików miejskich w Kaliszu, jak i na rozstrzyganie przez nich konfliktów moralnych. Co więcej, w badanym okresie 10 lat wyraźnie zmniejszyl się odsetek tych respondentów, którzy respektowali znaczenie autorytetów religijnych w swoim życiu i moralności, a zarazem wzrósł odsetek tych, którzy rolę tych autorytetów kwestionowali i zdecydowanie odrzucali, nie widząc potrzeby korzystania $\mathrm{z}$ ich pomocy ${ }^{16}$. Respondenci kwestionujący wpływ księży na sumienie ludzi, uzasadniali własny pogląd różnymi powodami i motywami. Wśród wysuwanych uzasadnień bardzo często pojawiało się stwierdzenie, iż ,sprawy sumienia są wyłącznie ich osobistym problemem, największą tajemnicą, a ich sumienie może samo rozstrzygnąc sprawy sporne, nie uciekając się po pomoc do autorytetów zewnętrznych, w tym religijnych i kościelnych". Stanowisko to może oznaczać, jak interpretuje je choćby Adam Podgórecki, iż w środowisku miejskim dziś są wyraźnie upowszechniane i eksponowane postawy celowościowe ${ }^{17}$. W postawach tych dominują wątpliwości co do celowości norm religijnych (nakazów i zakazów) i ich przydatności życiowej. We wzorze osobowym czlowieka postawy celowościowe mają charakter racjonalny i sprzyjają powstawaniu sytuacjonizmu etycznego. W postawach moich respondentów, zwlaszcza z drugiego terminu badań, sytuacja taka byla widoczna jasno i sugerowała eskalację owego sytuacjonizmu czy też relatywizmu moralnego.

W podsumowaniu tej kwestii należy zaznaczyć, iż postawy badanych katolików miejskich wobec norm moralności (dyscypliny) kościelnej (rytualnej) nie są jednolite - niektóre normy są akceptowane przez większe, a inne przez mniejsze odsetki respondentów. Różna także jest ocena badanych katolików dotycząca roli norm rytualnych w życiu religijnym ludzi. Jeśli na znaczenie postu w religijności wskazało ogólem $65,7 \%$ i $57,4 \%$ badanych katolików kaliskich, w tym $14,3 \%$ i $8,5 \%$ bez żadnej wattpliwości, to sankcję grzechu ciężkiego za umyślne opuszczenie mszy niedzielnej i świątecznej akceptowało już jedynie 44,9\% i 35,8\% badanych katolików. Fakt ów oznacza, że w badanym środowisku miejskim Kalisza słabnie wyraźnie utrwalony rytualizm i instytucjonalizm religijny ${ }^{18}$, a coraz

${ }^{16}$ Por. W. Piwowarski: Religtjność miejska w rejonie uprzemysłowionym, dz. cyt., s. 229 (Autor informuje tu, że w innych miastach polskich, rolę sumienia w moralności ludzi eksponowały następujące odsetki respondentów: w Płocku - 86,7\%, w Nowej Hucie - 83,7\%. Z kolei na rolę nakazów religijnych wskazały tam już mniejsze ich odsetki: 20,9\% i 33,0\%. Z rad księży skorzystato jedynie $5,9 \%$ i $7,8 \%$ badanych katolików miejskich).

${ }^{17}$ Zob. A. Podgórecki (i inni): Poglady spoleczeństwa polskiego na moralność i prawo. Warszawa 1971 s. 264.

${ }^{18}$ Zob. I. Borowik: Procesy instytucjonalizacji i prywatyzacji religii w powojennej Polsce. UJ, Krakôw 1997 s. $72-77$. 
częściej i liczniej pojawiają się postawy wybiórcze, selektywne, niezdecydowa$\mathrm{ne}^{19}$. Postawy te są widoczne szczególnie wyraźnie wśród imigrantów wiejskich zamieszkałych $\mathrm{w}$ mieście, a wyrażają się $\mathrm{z}$ jednej strony w odmowie posłuszeństwa Kościołowi i duchowieństwu, w krytycznym podejściu do norm i dyscypliny kościelnej, a z drugiej strony w akcentowaniu roli własnego sumienia, w niezależności własnych opinii i ocen w sprawach religijnych, w pomniejszaniu znaczenia autorytetów religijnych $w$ moralności i w dążeniu do autonomizacji postaw i działań jednostek ludzkich. Akceptacja norm rytualnych jest uzależniona w dużej mierze od poziomu zaangażowania religijnego jednostki. Wśród osób glęboko wierzących i wierzących występuje silniejsze oddziaływanie religijności tradycyjnej, akcentującej wierność i lojalność względem praktyk religijnych, a w efekcie wierność normom rytualnym, nakazującym wypełnianie praktyk religijnych. W przekonaniu tych katolików, normy rytualne maja zarówno fakultatywny, jak i obligatoryjny charakter. Z kolei dla osób niewierzących normy rytualne nie mają mocy obowiązującej, a sankcje chroniące skuteczności tych norm, nie są brane pod uwagę i nie mają żadnego znaczenia. Odstępowanie od rytualizmu w postawach wobec religii w środowisku miejskim ma konsekwentnie reperkusje w plaszczyźnie zachowań rytualnych katolików. Zachowania te ukażę w dalszej analizie niniejszego problemu.

\section{Zachowania rytualne badanych katolików miejskich}

Zachowań rytualnych w Kościele katolickim jest wiele i w różnym stopniu jest przestrzegane ich spełnianie przez jednostki i zbiorowości religijne. We własnych badaniach uwage zwróciłem na dwa zachowania rytualne katolików miejskich - na zachowywanie postów w dni wskazane przez przepisy kościelne oraz na przestrzeganie poszanowania niedzieli i świat religijnych jako „,czasu świętego", chronionego przed profanacja (E. Durkheim), przez powstrzymywanie się od wykonywania niekoniecznych, ciężkich prac użytecznych i przeznaczanie tego czasu na modlitwę, refleksję religijną i duchową oraz na racjonalny odpoczynek. Należy zaznaczyć, iż w analizie tych zagadnień będę opierał się na deklaracjach swobodnych moich respondentów, a to zawsze stwarza możliwość

${ }^{19}$ Zob. J. Mariański: Religia i Kościół w społeczeństwie pluralistycznym. KUL Lublin 1993; Tenże: Autorytet moralny Kościola w III Rzeczpospolitej. W: W. Zdaniewicz (red.): Znaczenie Kościola w pierwszych latach III Rzeczpospolitej. Warszawa 1994; D. Martin: Religion in Contemporary Europe. W: J. Fulton, P. Gee (red.): Religion in Contemporary Europe. New York 1994; P. Michel: Religion. Communism and Democracy in Central Europe. The Polish Case. W: W.H., Jr. Swatos: Politics and Religion in Central and Eastern Europe. Traditions and Transitions. Westport 1994; E. Morawska: Civil Religion vs. State Power in Poland. „Society”. Vol. 21: 1984 nr 4. 
odchyleń od stanu obiektywnego badanej rzeczywistości.

\section{Zachowywanie postów nakazanych katolikom przez Kościół}

Chociaż Kościól zmodernizował po II Soborze Watykańskim własne przepisy dotyczące postów jako zachowań rytualnych, ustanawiając jedynie kilka dni w roku, w których katolicy powinni powstrzymać się dobrowolnie od spożywania pokarmów mięsnych, a zarazem udzielając dyspensy w niektórych sytuacjach życiowych od tego wymagania licznym osobom, to $\mathrm{z}$ drugiej strony nadal zaleca w swej nauce moralnej zwiększoną troskę o zintensyfikowanie osobistej pobożności z pomocą rytuałów religijnych. Troska ta obejmuje również umartwienie i ascezę życia osobistego, zalecając wierzącym przestrzeganie normy nakazującej zachowywanie postu w dni zwykłe (piątki) i w dni o szczególnym charakterze pokutnym - w Srodę Popielcowa, w Wielki Piątek. W związku z tym interesowato mnie zagadnienie, w które dni wskazane przez Kościól, moi respondenci zachowują post i jakimi motywami uzasadniają własną decyzję, czyli postawę do normy rytualnej zalecającej im post? Wypowiedzi ich na to pytanie ilustruje tabela 5 , biorąc pod uwage wyniki z obu badań.

Analizując wyniki badań, nie trudno zauważyć, iż zachowywanie postu w obu terminach wskazanych przepisami kościelnymi, jest bardzo zróżnicowane i niejednolite. Norma rytualna nakazująca zachowywanie postu jest łamana przede wszystkim w ,zwykle” piatki tygodnia gdyż jedynie znikome odsetki $(28,8 \%$ i $24,1 \%)$ pościło w te dni. W drugim terminie badań widzimy spadek odsetka osób zachowujących regularnie post w piątek, a zarazem wzrost odsetka poszczących wtedy nieregularnie. Spożywanie pokarmów mięsnych w piątki jest zjawiskiem częstszym wśród wychodźców ze wsi osiadłych w mieście (o 4,6\% i o $12,5 \%$ ) niż w środowisku rdzennej ludności miejskiej. Stąd imigranci wiejscy rzadziej poszczą w piątki niż rdzenni kaliszanie. Wśród licznych czynników tej dysproporcji ważne miejsce zajmują odrębne zwyczaje kulturowe i kulinarne funkcjonujące na wsi i w mieście, rzutujące wprost na przyzwyczajenia i zachowania reprezentantów tych środowisk związane $\mathrm{z}$ dietą codzienną i odświętna. Wychodźcy ze wsi częściej i liczniej niż autochtoni miejscy lamia wzorce rytualne dotyczące choćby postu czy innych zwyczajów lokalnych ${ }^{20}$. W badanym środowisku miejskim dostrzegłem wzrost postaw krytycznych wobec rytualnej dyscypliny kościelnej w tym okresie, a postawa ta wplynęła na wzrost odsetka katolików, którzy świadomie nie zachowywali postu w piatki, niezależnie od tego, iż duży ich odsetek $65,7 \%$ i $58,4 \%$ widział w poście piątkowym czynnik dynamizu-

${ }^{20}$ Zob. W. Piwowarski: Religijność wiejjska w warunkach urbanizacji, dz. cyt., s. 246-247 (Autor informuje, że w rejonie wiejskim Puław 49,5\% katolików spożywało pokarmy mięsne w zwykłe piątki, motywując to zachowanie różnymi powodami i przyczynami). 
jący religijność jednostki i rodziny.

Tabela 4. Zachowywanie postı w terminach wskazanych przez Kościól

\begin{tabular}{|l|cc|cc|ccc|cc|}
\hline \multirow{2}{*}{$\begin{array}{c}\text { Przestrzeganie } \\
\text { zalecenia }\end{array}$} & \multicolumn{4}{|c|}{ Badania I } & \multicolumn{4}{c|}{ Badania II } \\
\cline { 2 - 11 } & \multicolumn{2}{|c|}{ Piątek } & \multicolumn{2}{|c|}{ Wielkie święta } & \multicolumn{2}{c|}{ Piątek } & Wielkie święta \\
\hline Zawsze & 249 & 20,3 & 888 & 72,6 & 165 & 13,8 & 668 & 55,7 \\
\hline Niekiedy & 105 & 8,5 & 65 & 5,3 & 124 & 10,3 & 102 & 8,5 \\
\hline Nigdy & 761 & 62,2 & 203 & 16,6 & 842 & 70,1 & 346 & 28,8 \\
\hline Nie wiem & 81 & 6,6 & 46 & 3,9 & 36 & 3,1 & 55 & 4,6 \\
\hline Brak danych & 26 & 2,4 & 20 & 1,6 & 33 & 2,7 & 29 & 2,4 \\
\hline Ogółem & 1222 & 100,0 & 1222 & 100,0 & 1200 & 100,0 & 1200 & 100,0 \\
\hline
\end{tabular}

Zasadniczo odmiennie kształtuje się sytuacja postu w ważne święta religijne i kościelne, kiedy do zdecydowana większość katolików miejskich, zwłaszcza w latach osiemdziesiątych, przestrzegała tę normę rytualna, czyli w Środę Popielcowa, w Wielki Piątek i w wigilię Bożego Narodzenia. Jednakże te trzy święta nie maja identycznej wartości $w$ ocenach respondentów, stąd różne ich odsetki zachowywaly post $\mathrm{w}$ ich czasie. Zdecydowanie największa liczba katolików pościła w Wielki Piątek, a najmniejsza w wigilię Bożego Narodzenia, zaś pośrodku jest Środa Popielcowa. W badanym dziesięcioleciu zmniejszył się jednak o 13,7\% odsetek osób zachowujacych post w te święta kościelne, w tym zwlaszcza tych, którzy w $1987 \mathrm{r}$. stwierdzili, iż dotąd wówczas zawsze postu przestrzegali, o $21,9 \%$. A zatem ponad 1/5 badanych katolików w latach dziewięćdziesiątych zrezygnowała świadomie $\mathrm{z}$ zachowywania postu także $w$ tych okresach kalendarza kościelnego. Ci respondenci wlaśnie stwierdzili w 1997 r., że post i inne rytuały religijne nie maja większego znaczenia $w$ ich religijności, jak i nie lączą ich ściślej $z$ Kościołem ${ }^{21}$. Ponadto, co istotne, pewien odsetek respondentów nigdy, w obu tych sytuacjach, nie zachowywał postu nakazanego przez Kościól - w pierwszym terminie był to średnio co trzeci $(39,4 \%)$, a w drugim terminie niemal co drugi $(49,4 \%)$ badany katolik.

${ }^{21}$ Zob. W. Piwowarski: Religıjność miejska w rejonie uprzemysłowionym, dz. cyt., s. 250 (Autor informuje, iż w Puławach zachowywało post w wielkie święta religijne 88\% katolików i 89,2\% w Kazimierzu); por. J. Mariański: Religia i Kościól w społeczeństwie pluralistycznym. Polska lat dziewięćdziesiatych. KUL Lublin 1993 s. 141-159. 
Na pytanie, dlaczego ktoś zachowuje post w dni wskazane przez Kościól, albo też lamie to zalecenie i spożywa wtedy pokarmy niedozwolone, uzyskałem różne argumentacje i powody. Spożywanie pokarmów mięsnych w piątki uzasadniano takimi choćby motywami i powodami, jak: żywienie się w stołówkach zbiorowych $(28,9 \%$ i $34,3 \%)$, ciężka praca fizyczna $(16,9 \%$ i $32,8 \%)$, sytuacja żywienia rodzinnego $(10,4 \%$ i $38,3 \%)$, częste podróżowanie $(8,2 \%$ i $26 \%)$, brak własnego poglądu ujawniło tu $12,8 \%$ i $28,3 \%$ respondentów. Na szczególną uwagę zasługuje tu motyw odrzucenia zwyczaju religijnego (23,5\% i 37,7\%), ponieważ respondenci, którzy w ten właśnie sposób uzasadnili własny negatywny stosunek do normy rytualnej nakazującej im zachowanie postu, świadomie zakwestionowali znaczenie religijnych tradycji i stwierdzili zarazem, że post nie ma żadnego znaczenia $w$ ich żuciu religijnym. Motywy zaprezentowane wyżej świadczą także o tym, iż respondenci nie zachowujący postu, raczej optują za konsumpcyjnym stylem życia na co dzień. W tym stylu częściej wygoda i sytość może mieć miejsce, niż umartwienie i umiar, z czym okresowa wstrzemięźliwość od pokarmów zabronionych rytuałem religijnym ma związek bezpośredni, jeśli jest podejmowana dobrowolnie i z motywów religijnych. Wtedy może ona powodować intensywność religijności i duchowości katolika.

Inaczej jeszcze ksztaltują się wskaźniki zachowywania postu w piątki i wielkie święta religijne w zależności od poziomu religijności katolików. Najliczniej wtedy zachowują post osoby głęboko wierzące (w piątki $72,6 \%$ i 58,7\% i w wielkie święta $96,1 \%$ i $75,8 \%)$ oraz osoby wierzace $(58,6 \%$ i $36,7 \%$ oraz $90,8 \%$ i $82,3 \%)$. Wskaźniki te maleją radykalnie w grupie osób watpiących religijnie $(9,6 \%$ i $7,5 \%$ oraz $28,4 \%$ i $17,7 \%)$ i w grupie osób obojętnych religijnie (3,8\% i $2,9 \%$ oraz $18,3 \%$ i $14,9 \%)$. Z kolei w grupie osób niewierzących w obu terminach nikt nie pościł w piątki, a w Wielki Piątek i w wigilię Bożego Narodzenia zachowywało post 11,9\% i 8,5\% oraz w Środę Popielcową 7,5\% i 6,6\% respondentów.

\section{Akceptacja i stosowanie obowiązku poszanowania religijnego charakteru niedzieli i świąt kościelnych}

Trzecie przykazanie dekalogalne (,Pamiętaj, abyś dzien święty święcil”) nie przestało obowiązywać współczesnych katolików, a Kościół nie ,złagodził” jego surowości i bezwzględności normatywnej, ponieważ nie ma on takiej możliwości; z drugiej strony liczni katolicy nie wiedzą o tym i posądzają Kościół o zacofanie i konserwatyzm religijny. Stąd nadal na wszystkich katolikach spoczywa obowiązek poszanowania religijnego charakteru „dnia świętego" - niedzieli i innych świąt kościelnych, uznanie tych dni za „,zas należny Bogu” i przeznaczenia go na modlitwę i racjonalny odpoczynek. $Z$ drugiej strony wiadomo, że od pewnego okresu przykazanie to uległo wyraźnemu rozluźnieniu w praktyce religijnej pod wpływem zmian w warunkach codziennego życia ludzi, w wyniku 
przeobrażeń $\mathrm{w}$ ich wierzeniach i praktykach rytualnych. W niedziele i święta pracują obecnie nie tylko robotnicy i rolnicy, lecz również coraz liczniej urzędnicy i nauczyciele, a w tym osoby duchowne uczace choćby w uczelniach wyższych. Większość katolików świeckich jest zdania, że księża także pracuja w „czasie świętym", spełniając własne zadania duszpasterskie w parafiach i we wspólnotach zakonnych czy w sanktuariach religijnych. Podobną opinię w tej sprawie wyraziło aż 89,4\% księży żonatych, którzy porzucili stan kapłański oraz $57,4 \%$ księży czynnych w strukturach kościelnych ${ }^{22}$.

W związku z tym można zapytać, kiedy ludzie mają odpoczywać, regenerować niezbędne siły fizyczne i duchowe do dalszej intensywnej pracy zawodowej, jeśli nie przestają wykonywać swych obowiązków nawet w niedziele i święta religijne? Kiedy ludzie wierzący mają spełniać własne praktyki religijne, jeśli w niedziele i święta idą do zakładów pracy, urzędów i szkół czy uczelni wyższych (tzw. studia zaoczne), zamiast pójść do kościoła na modlitwę? Czy pod wplywem postępującej desakralizacji warunków życia i stylu bycia ludzi na co dzień, w świadomości katolików zachowało się jeszcze poczucie obowiązku świętowania „dni świętych” i wola powstrzymania się od zbędnych prac i zajęć w tym czasie kosztem utraty modlitwy i religijnego spędzania czasu tych dni? Pytania te łączą się ściśle z tematem moich badań w Kaliszu, więc postawilem je także własnym respondentom. Ponadto, zapytałem ich o to, czy obecnie ma sens trzecie przykazanie dekalogalne? Czy sami pracuja w niedziele i święta kościelne, wykonując zajęcia zabronione normami religijnymi, i czy pracuja wtedy systematycznie? W jaki sposób odpoczywają w dni świąteczne i niedziele? Postawy badanych katolików wobec normy religijnej nakazującej im uszanowanie religijnego charakteru niedzieli i świąt kościelnych ilustruje tabela 6, uwzględniając wyniki obu badań środowiskowych na ten temat.

Tabela 5. Postawy katolików wobec obowiązku poszanowania religijnego charakteru niedzieli i świąt kościelnych

\begin{tabular}{|l|r|r|r|r|}
\hline \multirow{2}{*}{$\begin{array}{c}\text { Swiętowanie } \\
\text { niedzieli }\end{array}$} & \multicolumn{2}{|c|}{ Badania I } & \multicolumn{2}{c|}{ Badania II } \\
\cline { 2 - 5 } & \multicolumn{1}{|c|}{ Liczba } & \multicolumn{1}{c|}{ Procenty } & \multicolumn{1}{c|}{ Liczba } & \multicolumn{1}{c|}{ Procenty } \\
\hline Akceptuje & 848 & 69,4 & 619 & 51,6 \\
\hline Nie akceptuje & 175 & 14,3 & 338 & 28,2 \\
\hline
\end{tabular}

${ }^{22}$ Zob. J. Baniak: Wierność powolaniu a kryzys tożsamości kapłańskiej. Studium socjologiczne na przykładzie Kościoła w Polsce. WT UAM Poznań 2000; Te nże: Rezygnacja z kapłaństwa $i$ wybór życia malżeńsko-rodzinnego przez księży rzymskokatolickich w Polsce. Studium socjologiczne. NOMOS Kraków 2001. 


\begin{tabular}{|l|r|r|r|r|}
\hline & \multicolumn{3}{|c|}{ Badania I } & \multicolumn{2}{|c|}{ Badania II } \\
\hline To zależy & 127 & 10,4 & 147 & 12,3 \\
\hline Brak zdania & 45 & 3,6 & 62 & 5,1 \\
\hline Brak danych & 27 & 2,3 & 34 & 2,8 \\
\hline Ogółem & 1222 & 100 & 1200 & 100 \\
\hline
\end{tabular}

Z badań wynika, iż nie wszyscy respondenci uznaja zasadność i słuszność normy religijnej nakazującej katolikom świętowanie niedzieli, lecz jedynie pewien ich odsetek. W analizowanym okresie 10 lat odsetek ten jeszcze zmalał o niespełna osiem procent, a jednocześnie wzrósł o 14\% odsetek katolików, którzy zdecydowanie kwestionowali i odrzucili ten obowiązek religijny. Fakt ten oznacza także tendencję ujemną w ich moralności rytualnej. W tym czasie wzrósł także wskaźnik osób, które nie potrafiły zajać racjonalnego stanowiska w tej kwestii. Postawa ta może świadczyć o ich obojętnym stosunku do religii i moralności katolickiej, w skład której wchodzą analizowane normy rytualne.

Wykonywanie pracy w niedziele i święta badani katolicy uzasadniali różnymi motywami i powodami, bardziej lub mniej sensownymi i przekonującymi. Motywy te były dość ściśle powiązane z charakterem i trybem zajęć wykonywanych zawodowo, ze środowiskiem zamieszkania, z potrzebami finansowymi rodziny, $z$ koniecznością rozwoju firmy, z potrzebami osobistymi jednostki, $z$ chęcia zgromadzenia większych środków i nabycia cenniejszych dóbr użytecznych, jak choćby samochodu, sprzętu komputerowego, telewizora czy mebli domowych. Nie zabrakło i takich respondentów, którzy podejmowali prace zarobkowe w dni świąteczne i niedziele dlatego, żeby mogli opłacić sobie czesne za podjęte studia wyższe, czy też pokryć koszty studiów wlasnych dzieci. Sytuację tę lepiej zilustrują wybrane przykłady wypowiedzi respondentów na ten temat: „Mam pełne ręce roboty, mnóstwo spraw nie załatwionych dotąd, na które zabrakło mi już czasu w ciagu tygodnia. Czekam więc na niedzielę, żeby to wszystko uregulować. Chciałabym odpoczać w tym czasie, ale jest to niewykonalne praktycznie. Lecz czy Pan widział kobietę, która w niedzielę odpoczywa, jeśli jest żoną i matką kilkorga dzieci? Ja nie mam wtedy czasu na nic, nawet nie zawsze chodzę na mszę do kościoła, nie mówiąc już o spacerze z mężem lub z dziećmi. Obawiam się tylko, żeby w tym kieracie nie zapaść na jakąś chorobę" stwierdzila trzydziestodwuletnia matka trojga małych dzieci, pracująca zawodowo. Inna jeszcze wypowiedź: „W domu jest wiele pracy, ja od pół roku remontuję mieszkanie, a w niedziele robi się to najlepiej, bo nikt wtedy nie przeszkadza. 
Byle tylko nie przeszkadzać sąsiadom w odpoczynku, bo pomyśla sobie, jaki to ze mnie bezbożnik, który nawet dnia bożego nie uszanuje normalnie" - której autorem jest trzydziestosześcioletni mężczyzna, ojciec pięcioosobowej rodziny, pracujący na 1,5 etatu w charakterze murarza. Wypowiedź mlodej kobiety studiującej jest też ciekawa: „Moim marzeniem zawsze były studia wyższe, chciałam zostać lekarką, lecz nie mogłam pozwolić sobie na te studia ze względów rodzinnych i zwyczajnej biedy. Po maturze podjęłam pracę urzędnicza, a później dostałam się na studia marketingowe trybem zaocznym. Zarobione pieniądze przeznaczam w większości na pokrycie kosztów studiowania, i na życie zostaje mi nie wiele. Ale mimo to jestem szczęśliwa, bo mogę studiować i realizować choćby częściowo marzenia. W niektóre niedziele dorabiam sobie pracą fizyczną, kiedy nie mam zajęć na uczelni. Nie mam więc czasu chodzić do kościoła i na modlitwę, ani też na wypoczynek. Myślę jednak że Pan Bóg wybaczy mi ten grzech, jeśli nie dal mi równej szansy z innymi ludźmi młodymi". Wypowiedzi odznaczających się podobną treścia jest bardzo wiele, niektóre są jeszcze bardziej dramatyczne. Wszystkie one ukazują jasno, że zmieniło się dość radykalnie nastawienie katolików polskich do norm religijnych i moralnych, w wyniku czego kwestionują je oni i odrzucają, opowiadając się zarazem za normami świeckimi, którymi regulują własne postępowanie codzienne. Inaczej mówiąc, wyniki badań przemawiają za obniżeniem się poziomu kultury religijnej, w szczególności zaś wskazują na przemiany w kulturze świętowania religijnego w rodzinach i wspólnotach katolickich w Polsce, w których od pewnego czasu jest widoczny kryzys postaw i zachowań religijnych. Kryzys ten obją przede wszystkim religijny charakter niedzieli i wielu świąt kościelnych, w efekcie którego katolicy coraz częściej przestają dostrzegać dni święte i zarazem wypaczają ich istotę przez wykonywanie zbędnych prac użytecznych, albo wymuszając na sobie ich podejmowanie i realizację. Katolicy ci już świadomie zamieniają religijny charakter niedzieli i świąt na charakter świecki, zapominają o modlitwie i o jej roli w swej religijności, a liczni rodzice przekazują w ten sposób te zwyczaje i laicki styl życia wlasnym dzieciom, nie zastanawiając się często na konsekwencjami takiego postępowania i wychowania ${ }^{23}$.

Jeśli tak duży odsetek badanych katolików miejskich wykonywał w dni święte wiele różnych prac i zajęć, lekceważąc zarazem w ten sposób ich religijny charakter i cel, to nasuwa się pytanie, czy i w jakich formach odpoczywali oni w niedziele i święta? W pytaniu prosiłem respondentów, żeby wskazali najczęstsze formy własnego wypoczynku niedzielnego i świątecznego. Wypowiedzi ich na to

${ }^{23}$ Zob. J. Komorowska: Świqteczne zwyczaje domowe w wielkim mieście. W: Rytual religijny w rodzinie. Warszawa-Poznań 1988 s. 89-104; J. Mariański: Rytual chrztu w świadomości katolików polskich, tamże, s. 105-137; J. Baniak: Pierwsza komunia w Polsce. Istota $i$ wypaczenia. „Materiały Problemowe”. R. 1987 nr 5 s. $47-54$. 
pytanie ilustruje tabela 7 , zestawiając wyniki obu badań.

Tabela 6. Najczęstsze formy wypoczynku niedzielnego i świątecznego wskazane przez respondentów

\begin{tabular}{|l|r|r|r|r|}
\hline \multirow{2}{*}{ Formy wypoczynku } & \multicolumn{2}{|c|}{ Badania I } & \multicolumn{2}{c|}{ Badania II } \\
\cline { 2 - 5 } & \multicolumn{1}{|c|}{ Liczba } & \multicolumn{1}{c|}{ Procenty } & \multicolumn{1}{c|}{ Liczba } & \multicolumn{1}{c|}{ Procenty } \\
\hline Działka własna & 146 & 11,9 & 268 & 22,3 \\
\hline Spacer rodzinny & 570 & 46,6 & 642 & 53,5 \\
\hline Przyjęcia rodziny & 771 & 63,1 & 768 & 64,1 \\
\hline Telewizja & 961 & 78,8 & 1074 & 89,5 \\
\hline Kino & 408 & 33,4 & 326 & 27,2 \\
\hline Teatr & 267 & 21,8 & 235 & 19,6 \\
\hline Sport & 455 & 37,2 & 412 & 34,3 \\
\hline Sen & 366 & 30,1 & 264 & 22,1 \\
\hline Przyjaźń kolegów & 139 & 35,9 & 450 & 37,5 \\
\hline Czytanie książek & 181 & 14,2 & 211 & 17,6 \\
\hline Modlitwa, zaduma & 200 & 16,3 & 143 & 11,9 \\
\hline Msza w kościele & 762 & 62,3 & 537 & 44,7 \\
\hline Inne formy & 156 & 12,6 & 106 & 8,8 \\
\hline Brak danych & 1492 & 71 & 5,9 \\
\hline Podstawa procentów & & & 1200 & - \\
\hline
\end{tabular}

Analizując tabelę 7 widzimy, że większość respondentów preferuje trzy formy wypoczynku niedzielnego i świątecznego, nie doceniając jednocześnie form pozostałych. Inne formy bowiem wskazały już znacznie mniejsze odsetki badanych katolików. Na pierwszym miejscu w obu terminach respondenci wskazali na telewizję jako na formę własnego wypoczynku niedzielnego i świątecznego. $\mathrm{W}$ drugim terminie odsetek ich jest jeszcze większy i wzrósł o $10,7 \% \mathrm{w}$ stosunku do odsetka z pierwszego terminu. Wielu badaczy watpi jednak, czy 
można racjonalnie odpoczać podczas oglądania telewizji, zwlaszcza wtedy, kiedy czas oglądania jest zbyt duży, nadwerężając zdrowie psychiczne osoby korzystającej $z$ usług telewizji. Przesada w oglądaniu programów telewizyjnych najbardziej szkodzi dzieciom i mlodzieży, która ogląda je bezkrytycznie i namysłu. Dużą część winy za ten stan rzeczy ponoszą rodzice tych dzieci, nie świadomi często konsekwencji ,nadużywania” telewizji w życiu rodzinnym ${ }^{24}$. Ponad 3/5 respondentów $w$ obu terminach badań stwierdzily, że częstą formą wypoczynku niedzielnego i świątecznego w ich sytuacji są przyjęcia rodzinne - jak imieniny, urodziny czy inne okazje, jak i uroczystości świeckie wlasne lub sąsiadów. Niespełna $1 / 2 \mathrm{~W}$ pierwszym terminie oraz ponad $1 / 2$ respondentów $\mathrm{w}$ drugim terminie odpoczywa w niedzielę i święta udając się na spacer rodzinny, najchętniej do parku lub do innych miejsc oddalonych od własnego punktu zamieszkania. Tę formę wypoczynku cenią oni najbardziej ze względu na aktywność własna w tym czasie.

Wielu respondentów nie zapomina o istocie niedzieli i święta kościelnego, o ich religijnym charakterze i celu. Dlatego, jako katolicy, w te dni biorą udział w mszy i niekiedy w innych nabożeństwach celebrowanych w kościele parafialnym lub w innych świątyniach znajdujących się na terenie miasta Kalisza. Jeśli w pierwszym terminie o takim udziale w kulcie religijnym mówiło ponad $3 / 5$ badanych katolików, to w drugim terminie deklarację taką złożyło już o $1 / 5$ mniej w stosunku proporcjonalnym. Fakt ten może oznaczać laicyzację postaw respondentów i lekceważenie religijnego charakteru niedzieli i świąt kościelnych. Przemawiają za tym wnioskiem też znikome odsetki respondentów, którzy w tym czasie świątecznym modlą się indywidualnie we własnym domu rodzinnym, czy też podejmują refleksję religijną nad ważnymi problemami życiowymi i moralnymi. Co więcej, w drugim terminie badań zmalał znacznie odsetek tych respondentów, zwłaszcza wśród ludzi młodych i imigrantów wiejskich ${ }^{25}$.

W świetle zaprezentowanych tu badań można stwierdzić, iż postawy i zachowania rytualne katolików miejskich w Kaliszu są bardzo zróżnicowane i za-

${ }^{24}$ Zob. M. Wawrzak-Chodaczek: Miejsce telewizji w życiu codziennym rodziny. Wrocław 1997; J. Chrapek: Uwarunkowania recepcji programów telewizyjnych przez młodzież. Studium socjologiczne, KUL. Lublin 1985; E. Fleming: Telewizja w nauczaniu $i$ wychowaniu. Warszawa 1965; J. Gajda: Dziecko przed telewizorem. Warszawa 1977; J. Rudzki: Zafascynowanie telewizja. Warszawa 1967; Tenże: Telewizja w środowisku młodzieży wiejskiej. Warszawa 1963.

${ }^{25}$ Zob. W. Piwowarski: Proces sekularyzacji rodziny jako instytucji spoleczno-religijnej. „Roczniki Nauk Społecznych KUL”. T. 17: 1976 s. 93-123; J. Mariański: Kościót w społeczeństwie przemysłowym. Warszawa 1985; J. Bania k: Zróżnicowania i uwarunkowania religijności katolików Kalisza. Studium socjologiczne. Poznań 1992. 
leżne od licznych czynników. W przyjętym okresie 10 lat nastapiło wyraźne przesunięcie postaw i zachowań rytualnych katolików w kierunku (tendencji) ujemnym, typowo świeckim. Zjawisko to jest widoczne w sferze analizowanych tu norm i zachowań rytualnych, dowodząc niejednokrotnie wyraźnych sprzeczności $\mathrm{w}$ nastawieniu katolików do moralności rytualnej. W konsekwencji sprzeczności te świadczą o tym, iż w świadomości dużego odsetka badanych katolików miejskich dokonuje się szybka selekcja reguł moralnych dotyczących sfery dyscypliny kościelnej, sfery moralności rytualnej i moralności rodzinnej, jak i sfery transmisji wartości religijnych i kulturowych w warunkach międzygeneracyjnych. Znaczny też odsetek badanych katolików identyfikował się z tymi normami i postulatami rytualnymi Kościoła zaledwie fragmentarycznie i okazjonalnie. Ten ograniczony związek nie mógl pozostać obojętny dla sfery zachowań rytualnych tych katolików. Zachowania te często dalekie były od oczekiwań Kościoła i zarazem rzutowały wprost na poziom religijności badanych katolików. W badanym środowisku katolików miejskich w Kaliszu widoczne jest wyraźne odchodzenie od rytualistyki religijnej na rzecz rytualistyki świeckiej, zarzucanie wielu zachowań rytualnych, selektywność postaw wobec norm stanowiących rytualną dyscyplinę kościelną. W badanym dziesięcioleciu nastapiła więc znaczna zmiana w nastawieniu katolików Kalisza do moralności rytualnej o charakterze świeckim, widoczna tak w sferze postaw, jak i w sferze zachowań. 
